\title{
A Kinetics Model for Predicting Microcystis Growth Based on the Synergistic Effect of Nitrogen and Phosphorus on the Growth of Microcystis densa (Cyanobacteria)
}

\author{
Yangyang Cai ${ }^{1}$, Changyuan Tang ${ }^{2,1 *}$ \\ ${ }^{1}$ Sun Yat-sen University, School of Environmental Science and Engineering, Guangzhou, China \\ ${ }^{2}$ Sun Yat-sen University, School of Geography and Planning, Guangzhou, China
}

Received: 9 March 2020

Accepted: 28 June 2020

\begin{abstract}
Microcystis blooms occur frequently in subtropical lakes and reservoirs and cause serious ecological and economic losses. A novel Microcystis bloom caused by Microcystis densa has broken out in many reservoirs in South China. In order to control M. densa bloom, it is important to predict the growth of $M$. densa, which is influenced by the synergistic uptake and assimilation of nitrogen and phosphorus. Therefore, it is necessary to develop a model of the response of Microcystis growth to nitrogen and phosphorus concentrations. Our study focused on both nitrogen and phosphorus, and studied their synergetic effect on $M$. densa growth. The growth kinetics, including the maximum specific growth rates and the half-saturation constant of $M$. densa for both nitrogen and phosphorus, were also determined. A modified model with Monod kinetics was developed to explain the synergistic effects of nitrogen and phosphorus on $M$. densa growth. The specific growth rate of $M$. densa can be predicted by nitrogen and phosphorus concentrations. This modified model was verified by the actual measures of the Lianhe Reservoir and Liuxihe Reservoir. It could relatively accurately predict the growth level of $M$. densa and helped for the daily monitoring of reservoir management for $M$. densa growth.
\end{abstract}

Keywords: kinetics model, Microcystis densa, nitrogen, phosphorus, growth

\section{Introduction}

Cyanobacteria Microcystis blooms are common in many lakes and reservoirs where they usually cause negative consequences for environment and human health $[1,2]$. Usually, these Microcystis blooms are

*e-mail: abbeycai@sina.com cuased by Microcystis aeruginosa, which produces toxins that poison aquatic life [3]. However, A new Microcystis bloom caused by Microcystis densa has emerged in some subtropical reservoirs in southern China [4]. M. densa are common in rivers, lakes and reservoirs [5], but there is no or rarely reports of its bloom before 2012. However, a M. densa bloom has occurred every summer in Lianhe Reservoir since 2012, causing serious damage to the ecology. 
The mechanisms of Microcystis outbreaks have been studied, and it is suggested that their proliferation is the effect of multiple factors, such as the decrease in the ingestion rates of zooplankton, the weakening of the net flows of estuaries, and suitable temperatures and nutrients [6]. Among these, increasing nutrient inputs are widely considered an important factor for high densities of Microcystis [7]. Bioavailable nutrients concentrations, including nitrogen $(\mathrm{N})$ and phosphorus $(\mathrm{P})$, can affect the physiological conditions and the growth of Microcystis. M. densa belongs to Microcystis (Cyanobacteria) and it's growth is also affected by the concentrations of $\mathrm{N}$ and $\mathrm{P}$. Therefore, in order to timely detect fast growth of $M$. densa and take controlling measures for preventing bloom, establishing a $M$. densa growth model based on $\mathrm{N}$ and $\mathrm{P}$ concentrations in water column is necessary.

$\mathrm{N}$ is the crucial nutrient for Microcystis in temperate and subtropical lakes and reservoirs and affects photosynthesis and the biosynthesis of macromolecules, such as proteins, nucleic acids, and chlorophyll [8]. Nitrate $\left(\mathrm{NO}_{3}^{-}\right)$is the dominant form of dissolved inorganic nitrogen in most lakes and reservoirs and can be taken up by Microcystis for development [9, 10]. Although cells using $\mathrm{NO}_{3}^{-}$must induce the release of nitrate reductase and expend extra energy, $\mathrm{NO}_{3}^{-}$can be more readily accumulated within cells than other forms of nitrogen [11]. Comparing to $\mathrm{NO}_{3}^{-}$, ammonium $\left(\mathrm{NH}_{4}^{+}\right)$can be transported directly in algal cells without additional energy, but $\mathrm{NH}_{4}^{+}$concentration in natural water body is not very high, and excess cellular $\mathrm{NH}_{4}^{+}$ is toxic to algal cells [12]. Therefore, $\mathrm{NO}_{3}^{-}$is still considered the primary preferred nitrogen source for phytoplankton in the aquatic ecosystem.

$\mathrm{P}$ is also the essential nutrient that is required for the growth of Microcystis and their DNA, RNA, and energy transfer. Bioavailable phosphorus correlates with the abundance and growth rates of phytoplankton [13]. However, $P$ in many freshwater ecosystems is often found in a very low concentration, particularly in the surface layer $[14,15]$. Therefore, $\mathrm{P}$ is considered a key component in for Microcystis development [16]. Many studies have suggested that some cyanobacteria including Microcystis, can still bloom when the $\mathrm{P}$ concentrations is near or below detection limits [17]. Many studies also showed that $\mathrm{P}$ can be absorbed quickly into algal cells through alkaline phosphatase (AP) in the condition of phosphorus limitation. But the mechanism of enzyme production is closely related to the phosphorus concentration and algal species [18, 19]. Therefore, it is necessary to understand the effect of $\mathrm{P}$ on Microcystis growth at different concentrations, especially under very low concentrations of phosphorus.

The integrated function of nutrients on the growth rates and competing ability of phytoplankton has been the focus of increasing attention. Several studies reported that the stoichiometry of $\mathrm{N}: \mathrm{P}$ can successfully account for shifts in environmental changes and cellular conditions $[20,21]$. N and $\mathrm{P}$ can influence both the metabolism of algal cells and the production of organic compounds, which addresses the variation of cell growth rates and physiology and even affects the ability of phytoplankton to survive [22-24]. Therefore, the growth of Microcystis in natural water body is affected by $\mathrm{N}$ and $\mathrm{P}$ together. It should be considered simultaneously the effects of $\mathrm{N}$ and $\mathrm{P}$ on the growth of M. densa.

To understand the synergistic promoting mechanism of $\mathrm{N}$ and $\mathrm{P}$ the growth rate of $M$. densa, the affinity of $M$. densa for $\mathrm{N}$ and $\mathrm{P}$ was used to evaluate the ability of uptake and assimilation for nutrients, determining their growth rates and the ability to compete in the phytoplankton community. The affinity coefficients, including the maximum specific growth rate $\left(\mu_{\max }\right)$ and half-saturation constant $(\mathrm{K})$ of $M$. densa for $\mathrm{N}$ and $\mathrm{P}$, are the parameters which indicate the response of phytoplankton growth to nutrients. The $\mu_{\max }$ indicates that the ratio of cells increased from the previous day. The higher the $\mu_{\max }$ is, the faster the algal cells grow. The $\mathrm{K}$ indicates the ability of algal cells to get nutrients in oligotrophic lakes or reservoirs. The lower the $\mathrm{K}$ is, the lower the concentrations of nutrients that the algal cells can obtain. Therefore, a high $\mu_{\max }$ and low $\mathrm{K}$ could be beneficial to the competition of phytoplankton on nutrients. Most research has focused attention on the effects of a single nutrient $(\mathrm{N}$ or $\mathrm{P})$ rather than integrated $\mathrm{N}$ and $\mathrm{P}$ on the growth of $M$. densa. However, it is impossible to have a single nutrient in lakes and reservoirs, $\mathrm{N}$ and $\mathrm{P}$ usually worked together. Therefore, the integrated action of $\mathrm{N}$ and $\mathrm{P}$ on the growth of $M$. densa is particularly important. When the integrated values of $\mu_{\max }$ and $\mathrm{K}$ of $M$. densa for $\mathrm{N}$ and $\mathrm{P}$ were known, the biomass of $M$. densa could be estimated by measuring the nutrient concentrations.

In order to build a model which can predict $M$. densa growth, the objective of our work was to (1) quantitatively evaluate the mechanistic active growth model describing the response of $M$. densa growth to both $\mathrm{N}$ and $\mathrm{P}$, (2) provide the simplest model to describe $M$. densa growth performance based on the different concentrations of $\mathrm{N}$ and $\mathrm{P}$, (3) contribute to the understanding of the nutrient mechanisms of $M$. densa blooms in subtropical reservoirs, and (4) help to predict the growth of $M$. densa.

\section{Materials and Methods}

\section{Algal Strain and Culture Condition}

The Chinese strain of Microcystis densa (No. MD-1) was isolated from the water column of Lianhe Reservoir (231' $57.2^{\prime \prime} \mathrm{N}, 113^{\circ} 55^{\prime} 8.8^{\prime \prime} \mathrm{E}$ ) in Guangdong Province during a $M$. densa bloom in July 2017 and was maintained in the School of Environmental Science and Engineering, Sun-Yansen University, China.

Prior to the experiment, the culture of $M$. densa was re-inoculated 4 times during the exponential phase 
in BG-11 medium for Blue Green Algae [25]. $\mathrm{NaNO}_{3}$ was used to be $\mathrm{N}$ source in the media and the concentration was reduced gradually from 1.5 to 0.7 , and 0.1 , then to $0.05 \mathrm{~g} \mathrm{l}^{-1}$. $\mathrm{K}_{2} \mathrm{HPO}_{4}$ was $\mathrm{P}$ source and the concentration was from 40 to 10 , and 1 , then to $0.1 \mathrm{mg} \mathrm{l^{-1 }}$. The cultures were maintained at $28 \pm 1^{\circ} \mathrm{C}$ in a light dark cycle of 12:12 with irradiation of $100 \mu \mathrm{mol}$ photons $\mathrm{m}^{-2} \mathrm{~s}^{-1}$. The transfer of these cultures for continuous maintenance was conducted aseptically.

The antibiotics, including penicillin $G$ and streptomycin sulfate, were used to prevent bacterial contamination $48 \mathrm{nh}$ before the next inoculation [26]. The check for bacterial contamination using 4',6-diamidino2-phenylindole (DAPI) (Sigma) staining at regular intervals was made by microscopic inspection.

\section{The Growths of $M$. densa under N and P Substrates with Different Concentrations}

The initial cell densities of $M$. densa in the media of both $\mathrm{N}$ and $\mathrm{P}$ substrates were $\sim 0.1 \times 10^{6}$ cells $\mathrm{ml}^{-1}$. BG-11 medium was used for the culture of $M$. densa. For the experiment under $\mathrm{N}$ subtrates, $\mathrm{NaNO}_{3}$ as $\mathrm{N}$ substrates was added into the culture with the final concentrations of $0,0.001,0.01,0.05,0.1,0.5,1,2,4$, 8,20 and $40 \mathrm{mg} \mathrm{N} \mathrm{1}^{-1}$, while the $\mathrm{P}$ concentration was added according to BG-11 medium. For the experiment under $\mathrm{P}$ substrates, $\mathrm{K}_{2} \mathrm{HPO}_{4}$ as $\mathrm{P}$ substrates was added to the culture of $M$. densa with final concentrations of $0,0.001,0.005,0.01,0.02,0.04,0.08,0.1,0.5,1,10$, and $20 \mathrm{mg} \mathrm{P} \mathrm{l}^{-1}$, while the $\mathrm{N}$ concentration was added according to BG-11 medium. These treatments were all performed in triplicate, and were maintained at $28 \pm 1^{\circ} \mathrm{C}$ in a light dark cycle of 12:12 with an irradiation of $100 \mu \mathrm{mol}$ photons $\mathrm{m}^{-2} \mathrm{~s}^{-1}$.

The samples for the cell counts were obtained daily and were fixed in a $2 \%$ acid Lugol's solution. The cell density was measured with a Sedgwick-Rafter counting chamber under a fluorescence microscope CKX41 (Olympus, Japan) with 200-400 $\times$ magnification. The phytoplankton species were identified as suggested by $\mathrm{Hu}$ and Wei [5]. The specific growth rates $\left(\mu, \mathrm{d}^{-1}\right)$ of $M$. densa meant relative growth rate and were calculated according to the equation:

$$
\mu=\frac{\ln N_{2}-\ln N_{1}}{t_{2}-t_{1}}
$$

...where $N_{2}$ and $N_{1}$ were the cell densities of $M$. densa at days $t_{2}$ and $t_{1}$, respectively. In this study, for example, when the cell density of $M$. densa at day 1 was $N_{1}$ and the cell density at day 2 was $N_{2}$, the $\mu\left(\mathrm{d}^{-1}\right)$ was calculated: $\mu=\left(\ln N_{2}-\ln N_{1}\right) /(2-1)=\ln \left(N_{2} / N_{1}\right)$.

\section{Model Development}

The model was quantitatively evaluated to describe the specific growth rates of $M$. densa responding to different $\mathrm{N}$ and $\mathrm{P}$ concentrations. Based on the Monod equation [27], the specific growth rates of $M$. densa $\left(\mu, \mathrm{d}^{-1}\right)$ against the $\mathrm{N}$ and $\mathrm{P}$ concentrations were calculated as below, respectively:

$$
\begin{gathered}
\mu_{N}=\mu_{\max N} \frac{C_{N}}{K_{N}+C_{N}} \\
\mu_{P}=\mu_{\max P} \frac{C_{P}}{K_{P}+C_{P}}
\end{gathered}
$$

...where $\mu_{N}$, and $\mu_{P}$ are the specific growth rate of $M$. densa $\left(\mathrm{d}^{-1}\right)$ under $\mathrm{N}$, and $\mathrm{P}$ substrates, respectively; $\mu_{\max N}$, and $\mu_{\max P}$ are the maximum specific growth rates $\left(\mathrm{d}^{-1}\right)$ of $M$. densa for $\mathrm{N}$ and $\mathrm{P}$, respectively; $C_{N}$, and $C_{P}$ are the concentrations of $\mathrm{N}\left(\mathrm{mg} \mathrm{l}^{-1}\right)$, and $\mathrm{P}\left(\mathrm{mg} \mathrm{l}^{-1}\right)$ in the treatments, respectively. In addition, $K_{N}$ and $K_{P}$ are the half-saturation constants for the $\mathrm{N}\left(\mathrm{mg} \mathrm{l}^{-1}\right)$ and $\mathrm{P}\left(\mathrm{mg} \mathrm{l}^{-1}\right)$ substrates, respectively.

The specific growth rate of $M$. densa $\left(\mu_{A}\right)$ associated with the synergistic effects of $\mathrm{N}$ and $\mathrm{P}$ can be expressed in the form:

$$
\mu_{A}=\left(\mu_{\max N} \frac{C_{N}}{K_{N}+C_{N}}\right)\left(\mu_{\max P} \frac{C_{P}}{K_{P}+C_{P}}\right)
$$

...where $\mu_{A}$ is the specific growth rate of $M$. densa responding to both $\mathrm{N}$ and $\mathrm{P}$ substrates. Once the concentrations of nitrogen $\left(C_{N}\right)$ and phosphorus $\left(C_{P}\right)$ in the water column are known, the specific growth rate of $M$. densa cells $\left(\mu_{A}\right)$ can also be calculated to determine the growth status of $M$. densa. Combined with the results of field investigation, we believe that if $\mu_{A}$ increases continuously for $2 \sim 3$ days and the value is higher than $0.1 \mathrm{~d}^{-1}$, it is highly likely that $M$. densa cells have reached the exponential growth stage. At this time, it is necessary to take measures to prevent the further proliferation of $M$. densa.

$\mathrm{Q}_{\mathrm{N}}\left(\mathrm{pg} \mathrm{N}\right.$ cell $\left.^{-1}\right)$ and $\mathrm{Q}_{\mathrm{P}}\left(\mathrm{pg} \mathrm{P}\right.$ cell ${ }^{-1}$ ) were the minimum cell quota for $\mathrm{N}$ and $\mathrm{P}$, respectively. They derived from the number of $\mathrm{N}$ or $\mathrm{P}$ starved cells grown in the media with limited $\mathrm{N}$ or $\mathrm{P}$ concentrations, which can be expressed as below, respectively:

$$
\begin{aligned}
Q_{N} & =\frac{C_{N}}{N_{f N}-N_{i N}} \\
Q_{P} & =\frac{C_{P}}{N_{f P}-N_{i p}}
\end{aligned}
$$

...where $N_{f N}$ and $N_{i N}$ are the cell numbers at the stationary and initial phases of growth in $\mathrm{N}$ substrate, respectively, while $N_{f P}$ and $N_{i N}$ were those in P substrate, respectively.

\section{Model Verification}

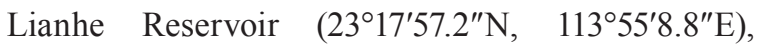
which is located in Guangdong Province, South China, is a typical canyon-shaped reservoir in the subtropical 


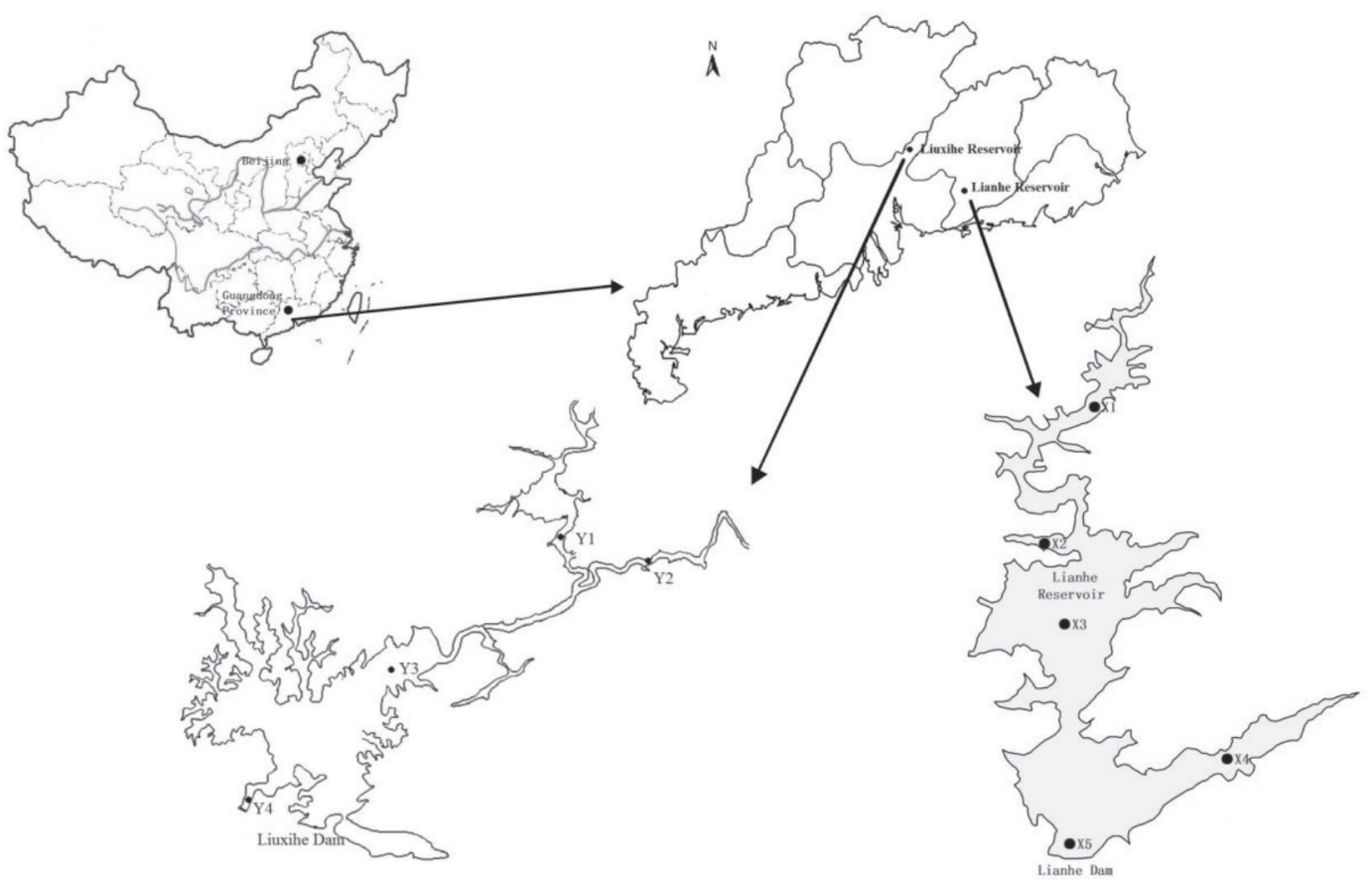

Fig. 1. Illustration of Lianhe Reservoir and Liuxihe Reservoir showing the location of sampling stations from 2014 to 2018.

region (Fig. 1). The dam was built at the southwest part of the study area in the 1970s and supports multiple purposes including drinking water supply, irrigation, hydroelectric power generation, and flood control. The hills surrounding the reservoir are covered with pine and spruce. There are also some villages and farmlands surrounding the reservoir. There are no industrial or urban pollution sources near the reservoir. Since the summer of 2012, a M. densa bloom has covered the reservoir and causes a highly publicized drinking water crisis.

Liuxihe Reservoir $\left(23^{\circ} 45^{\prime} 50^{\prime \prime} \mathrm{N}, \quad 113^{\circ} 46^{\prime} 52^{\prime \prime} \mathrm{E}\right)$, located in Guangdong Province, South China, is a large canyon-type reservoir on the north side of the tropic of cancer (Fig. 1). It was built in 1958, with a dam located in its southwestern. The inflow water of the reservoir mainly comes from two upstream tributaries. Natural forests are planted around the reservoir with little human intervention. The reservoir is an important drinking water source for downstream residents. However, $M$. densa bloom has occasionally occurred in the reservoir over the last decade.

\section{Sampling and Analysis}

Sampling was taken at $0.5 \mathrm{~m}$ below the water surface from X1 to X5 in June, July, and August 2015 2017 in Lianhe Reservoir and from Y1 to Y4 in June, July, August and September 2014 2018 in Liuxihe Reservoir (Fig. 1). The water temperature (WT), $\mathrm{pH}$ and dissolved oxygen (DO) were measured in situ using a multi-parameter water quality meter EXO2 (YSI, USA). The samples for TN and TP concentration analysis were collected in pre-sterilized $500 \mathrm{ml}$ polyethylene bottles in triplicate. They were transported to the laboratory as soon as possible and stored at $4^{\circ} \mathrm{C}$. After being filtered through $0.45 \mu \mathrm{m}$ cellulose acetate membranes (Whatman CA), TN and TP were carried out using standard combined persulfate digestion methods for water quality [28].

Water samples for determining the $M$. densa species and its cell density were also collected at $0.5 \mathrm{~m}$ below the surface from X1 to X5 in June, July, and August 2015 2017 in Lianhe Reservoir and from Y1 to Y4 in June, July, August and September 2014 2018 in Liuxihe Reservoir, respectively. Samples were collected in triplicate in 11 polyethylene bottles and were preserved with acidic Lugol's iodine solution (2\% final concentration) in situ for later enumeration using a sedimentation technique. M. densa was identified, as suggested by $\mathrm{Hu}$ and Wei [5]. The cell density was measured with a Sedgwick-Rafter counting chamber under a fluorescence microscope (Olympus, Japan) at 200-400 × magnification.

\section{Data Analysis}

A one-way ANOVA with a Tukey test was performed to compare the differences among the treatments of each test parameter. A $P$-value $<0.05$ was regarded as significant and $<0.01$ as highly significant. Prior to analysis, the data were tested for the normality and homogeneity of variation. A $\log 10$ or squareroot transformation of the data was performed prior to any statistical test when necessary. Statistical analysis was performed using SPSS 19.0 software (SPSS Inc., USA). 

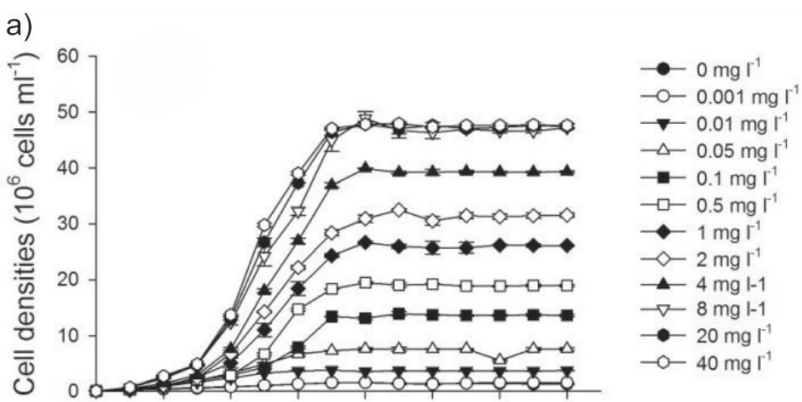

b)

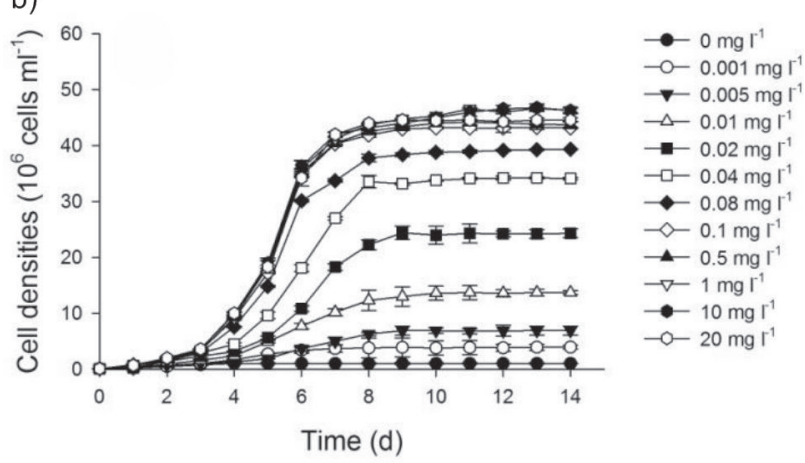

Fig. 2. The growth of $M$. densa during treatments with different concentrations of a) $\mathrm{N}$ and b) P. The values are the mean \pm S.D. $(\mathrm{n}=3)$.

\section{Results}

The Growth of M. densa under N and P Substrates with Different Concentrations

The $M$. densa cells in treatments grew well, except for those treatments that had $\mathrm{N}$ concentrations of 0 and $0.001 \mathrm{mg} \mathrm{l}^{-1}$, and their maximum cell densities appeared on Day 8 9 (Fig. 2a). The cells in the treatments of $0.01 \sim 40 \mathrm{mg} \mathrm{l}^{-1}$ were in the exponential growth stage from Day 3 and transitioned to the stationary phase after Day 9. The maximum cell densities in the treatments of 8,20 , and $40 \mathrm{mg}^{-1}$ $\left(47.8 \pm 0.3 \sim 48.8 \pm 1.2 \times 10^{6}\right.$ cells $\left.\mathrm{ml}^{-1}\right)$ were almost the same (Fig. 2a). The maximum cell densities in the concentrations of 0 and $0.001 \mathrm{mg} \mathrm{l}^{-1}$ were significantly lower than those in other treatments $(P<0.05)$, and neither of them reached the exponential growth stage.

$M$. densa cells responding to different $\mathrm{P}$ concentrations increased rapidly and achieved the exponential growth stage at Day 3, except the treatment of $0 \mathrm{mg} \mathrm{l}^{-1}$ (Fig. 2b). As the P concentrations increased, the maximum cell densities in each treatment gradually increased. When the $\mathrm{P}$ concentration exceeded $1 \mathrm{mg} \mathrm{l}^{-1}$, there was little difference in the growth curves between these treatments (Fig. 2b). The maximum cell density $\left(46.8 \pm 0.7 \times 10^{6}\right.$ cells $\left.^{-1}\right)$ was found at Day 14 . The cells reached the stationary phase after Day 9 .

Equations of specific growth rate curves fit well with the Monod equation with an $\mathrm{R}^{2}$ of 0.70 and 0.89 for $\mathrm{N}$ and $\mathrm{P}$ substrates, respectively (Fig. 3a; Fig. 3b). The $\mathrm{K}$ for $\mathrm{N}$ substrate $\left(0.15 \pm 0.02 \mathrm{mg} \mathrm{l}^{-1}\right)$ was significantly higher than that for $\mathrm{P}$ substrate $\left(0.03 \pm 0.00 \mathrm{mg} \mathrm{l}^{-1}\right)$ $(P<0.05)$ (Table 1). The maximum growth rates $\left(\mu_{m a x}\right)$ for $\mathrm{N}$ and $\mathrm{P}$ substrates were $0.53 \pm 0.03$ and $0.60 \pm 0.03 \mathrm{~d}^{-1}$, respectively (Table 1). M. densa had an approachable affinity to $\mathrm{P}$ substrate comparing to $\mathrm{N}$ substrate. The mean value of $\mathrm{Q}_{\mathrm{N}}\left(186.5 \mathrm{fg} \mathrm{N}^{\mathrm{N}}\right.$ cell $\left.^{-1}\right)$ was significantly higher than the value of $\mathrm{Q}_{\mathrm{P}}\left(71.7 \mathrm{fg} \mathrm{P}\right.$ cell $\left.^{-1}\right)(P<0.05)$ (Table 1).

\section{Model Evaluation and Parameters}

The modified model of the specific rates of growth of $M$. densa responding to the $\mathrm{N}$ under different $\mathrm{P}$ concentrations was shown, and all curves conformed to the Monod equation (Fig. 4). At the same concentration of $\mathrm{P}$, when $\mathrm{N}$ concentrations $<1 \mathrm{mg} \mathrm{l}^{-1}, \ln \left(\mu_{\mathrm{A}}\right)$ was positively proportional to the $\mathrm{N}$ concentrations, while $\mathrm{N}$ concentrations $\geq 1 \mathrm{mg} \mathrm{l}^{-1}$, the value of the $\ln \left(\mu_{\mathrm{A}}\right)$ reached a plateau. This indicated that adding the $\mathrm{N}$ concentration would only promote rapid reproduction of Microcystis in situations of lower $\mathrm{N}$ concentrations. Therefore, $\mathrm{N}$ concentration was a critical factor affecting the growth of M.densa.
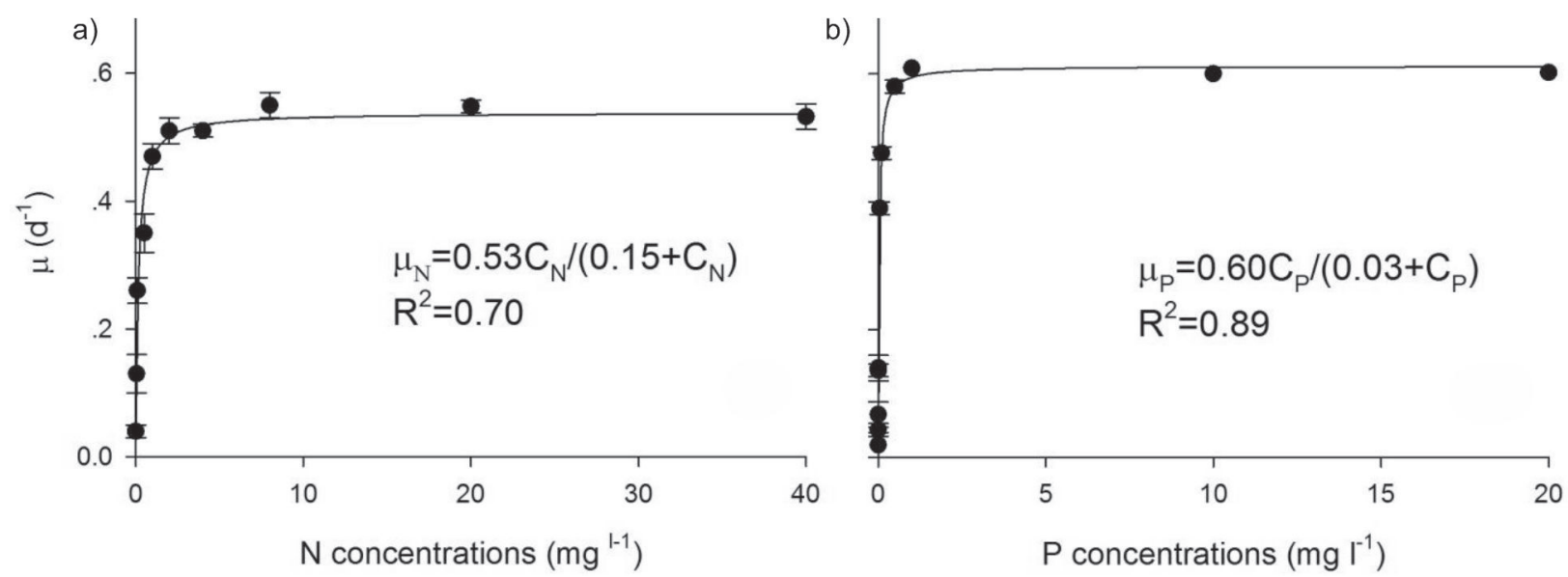

Fig. 3. The specific growth rates of $M$. densa $(\mu)$ under a) $N$ and b) P substrates. The values are the mean \pm S.D. $(n=3)$. 
Table 1. The calculated cell-specific parameters (the maximum specific growth rate, $\mu_{\max }$; the half-saturation constant for the substrate, $\mathrm{K}$; the coefficient of correlation, $\mathrm{R}^{2}$; and the minimum cell quota, Q) for the growth kinetics of $\mathrm{N}$ and $\mathrm{P}$ substrates by $M$. densa. The values are the mean \pm S.D. $(n=3)$.

\begin{tabular}{|c|c|c|c|c|}
\hline Substrate & $\mu_{\max }\left(\mathrm{d}^{-1}\right)$ & $\mathrm{K}\left(\mathrm{mg} \mathrm{l}^{-1}\right)$ & $\mathrm{R}^{2}$ & $\mathrm{Q}\left(\mathrm{fg}_{\text {cell }}{ }^{-1}\right)(\mathrm{mean} \pm \mathrm{S} . \mathrm{E})$. \\
\hline $\mathrm{N}\left(\mathrm{NO}_{3}{ }^{-}\right)$ & $0.53 \pm 0.03$ & $0.15 \pm 0.02$ & 0.70 & $186.5 \pm 277.3$ \\
\hline $\mathrm{P}^{\left(\mathrm{PO}_{4}^{3-}\right)}$ & $0.60 \pm 0.03$ & $0.03 \pm 0.00$ & 0.89 & $71.7 \pm 142.8$ \\
\hline
\end{tabular}

The model can also be calculated under other $\mathrm{P}$ concentrations (Table 2). With increasing $\mathrm{P}$ concentrations, the values of $\mu_{\text {max-A }}$ in the model became increasingly high. The lowest $\mu_{\text {max-A }}$ value was $0.01 \mathrm{~d}^{-1}$ when the $\mathrm{P}$ concentration was $0.001 \mathrm{mg} \mathrm{l}^{-1}$ and the highest was $0.31 \mathrm{~d}^{-1}$ when the $\mathrm{P}$ concentration was over $0.7 \mathrm{mg} \mathrm{l}^{-1}(P<0.05)$. However, when the $\mathrm{P}$ concentration was higher than $0.7 \mathrm{mg} \mathrm{l}^{-1}$, both the $\mu_{\text {max-A }}\left(0.31 \mathrm{~d}^{-1}\right)$ and $\mathrm{K}\left(0.15 \mathrm{mg} \mathrm{l}^{-1}\right)$ maintained at constant values. Therefore, the $\mathrm{P}$ concentration, like $\mathrm{N}$ concentration, was also a critical factor for controlling the growth of $M$. densa.

\section{Model Verification}

WT, $\mathrm{pH}$ and DO concentrations were similar in Lianhe Reservoir and Liuxihe Reservoir, with mean WT of 33.2 and $32.9^{\circ} \mathrm{C}$, mean $\mathrm{pH}$ of 8.1 and 8.2 , mean DO concentration of 8.7 and $8.2 \mathrm{mg} \mathrm{l}^{-1}$ in Lianhe Reservoir and Liuxihe Reservoir, respectively (Table 3). $\mathrm{NO}_{3}^{-}-\mathrm{N}$ and $\mathrm{PO}_{4}^{3-}-\mathrm{P}$ concentrations in Lianhe Reservoir were higher than those in Liuxihe Reservoir (Table 3). The variation range of $\mathrm{NO}_{3}^{-}-\mathrm{N}$ in Lianhe Reservoir was from 0.10 to $1.19 \mathrm{mg} \mathrm{l}^{-1}$ and the mean value was $0.59 \mathrm{mg} \mathrm{l}^{-1}$, while the variation range in Liuxihe Reservoir was $0.13 \sim 1.21 \mathrm{mg} \mathrm{l}^{-1}$ and the mean value was $0.51 \mathrm{mg} \mathrm{l}^{-1}$. The variations of $\mathrm{PO}_{4}^{3-}-\mathrm{P}$ were not significant in these two reservoirs $(p<0.05)$, with the concentration of $0.049 \mathrm{mg} \mathrm{l}^{-1}$ in Lianhe Reservoir and of $0.013 \mathrm{mg} \mathrm{l}^{-1}$ in Liuxihe Reservoir, respectively (Table 3).

Accordingly, the measured data from the Lianhe Reservoir and other documents [29-32] were used to verify the relationship between the specific growth rates of $M$. densa $\left(\mu_{\mathrm{A}}\right)$ and the concentrations of $\mathrm{NO}_{3}^{-}-\mathrm{N}$ and $\mathrm{PO}_{4}^{3-} \mathrm{P}$ (Fig. 5a). The modified model $\left(\mu_{\mathrm{max}-\mathrm{A}}=0.20 \mathrm{~d}^{-1}\right.$ and $\mathrm{K}_{\mathrm{N}}=0.15 \mathrm{mg} \mathrm{l}^{-1}$ ) was similar to the curve based on actual measures $\left(\mu_{\text {max }-\mathrm{A}}=0.19 \mathrm{~d}^{-1}\right.$ and $\left.\mathrm{K}_{\mathrm{N}}=0.12 \mathrm{mg} \mathrm{l}^{-1}\right)$ when the $\mathrm{PO}_{4}^{3-}-\mathrm{P}$ concentration was $0.05 \mathrm{mg} \mathrm{l}^{-1}$, which showed that our modified model was consistent with real cases.

The measured data in Liuxihe Reservoir were also used to verify the accuracy of the model (Fig. 5b). The $\mathrm{PO}_{4}^{3-}-\mathrm{P}$ concentration in Liuxihe Reservoir maintained at approximately $0.01 \mathrm{mg} \mathrm{l}^{-1}$ all the year around. Therefore, based on the $\mathrm{PO}_{4}^{3-}-\mathrm{P}$ concentration, the equation with $\mu_{\mathrm{A}}=0.08 \mathrm{C}_{\mathrm{N}} /\left(0.15+\mathrm{C}_{\mathrm{N}}\right)$ was chosen to used in predict the specific growth rate of $M$. densa (Table 2). According to the actual measurement results, the fitted equation with $\mu_{\mathrm{A}}=0.08 \mathrm{C}_{\mathrm{N}} /\left(0.16+\mathrm{C}_{\mathrm{N}}\right)$ is in good agreement with the modified model we calculated (Fig. 5b). It indicated that the model could accurately predict the growth status of $M$. densa according to the concentrations of $\mathrm{NO}_{3}^{-}-\mathrm{N}$ and $\mathrm{PO}_{4}^{3-}-\mathrm{P}$ in the water column.

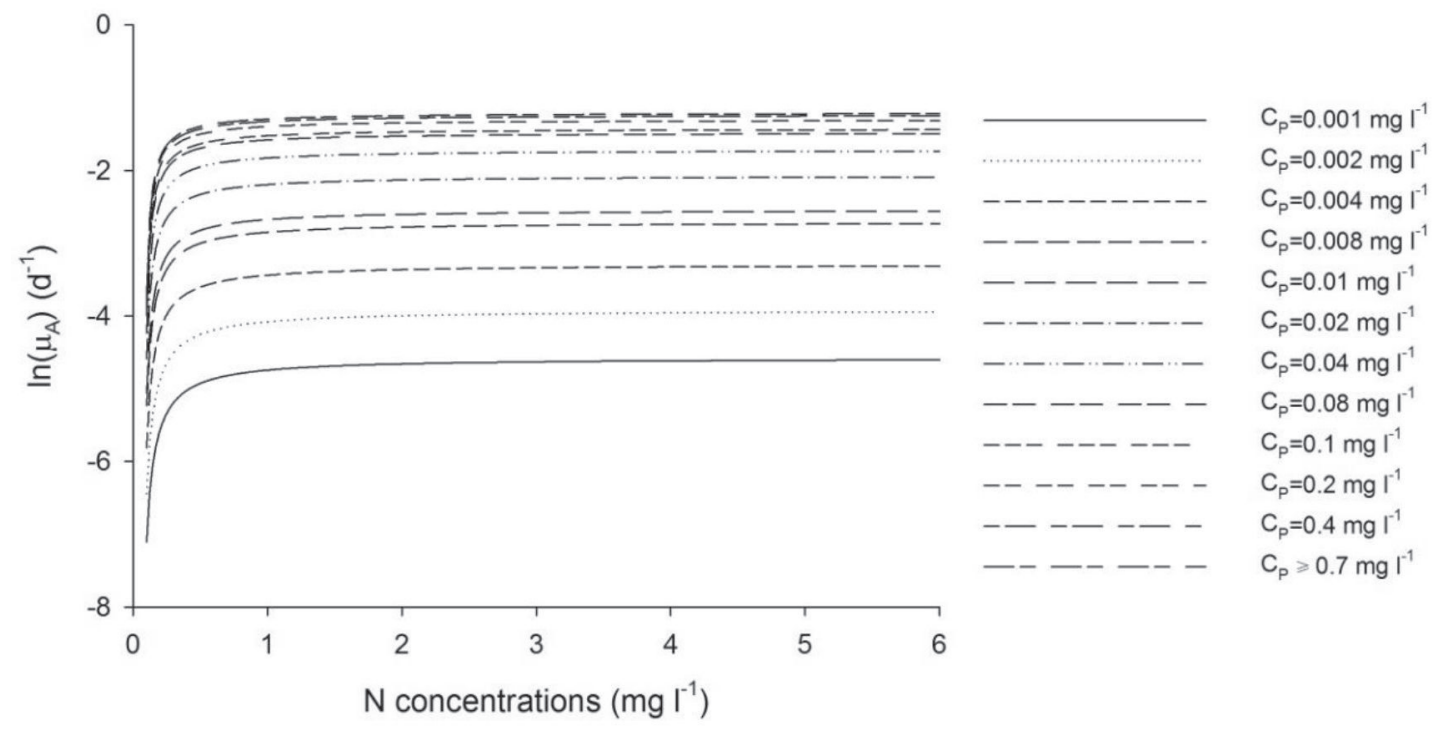

Fig. 4. The models of the specific growth rates of $M$. densa $\left(\mu_{\mathrm{A}}\right)$ responding to $\mathrm{N}$ concentrations based on different $\mathrm{P}$ concentrations. 
Table 2. The equations and correlation parameters, and the minimum ratios of $\mathrm{N}: \mathrm{P}$ while the $\mu_{\mathrm{A}}$ cells transition into the stable growth period, which corresponds to the calibrated models under different concentrations of the $\mathrm{P}$ substrate $\left(\mathrm{P}\right.$ concentrations, $\mathrm{C}_{\mathrm{P}}=0.001,0.002$, $0.003,0.004,0.005,0.006,0.007,0.008,0.009,0.01,0.02,0.03,0.04,0.05,0.06,0.07,0.08,0.09,0.1,0.2,0.3,0.4,0.5,0.6,0.7,0.8$, 0.9 , and $\left.1.0 \mathrm{mg} \mathrm{l}^{-1}\right)$.

\begin{tabular}{|c|c|c|c|c|}
\hline $\mathrm{C}_{\mathrm{p}}\left(\mathrm{mg} \mathrm{l}^{-1}\right)$ & Equations & $\mu_{\max -\mathrm{A}}\left(\mathrm{d}^{-1}\right)$ & $\mu_{\mathrm{p}}\left(\mathrm{mg} \mathrm{l}^{-1}\right)$ & $\mathrm{N}: \mathrm{P}$ \\
\hline 0.001 & $\mu_{\mathrm{A}}=0.01 \mathrm{C}_{\mathrm{N}} /\left(0.15+\mathrm{C}_{\mathrm{N}}\right)$ & 0.01 & 0.02 & 2214.3 \\
\hline 0.002 & $\mu_{\mathrm{A}}=0.02 \mathrm{C}_{\mathrm{N}} /\left(0.15+\mathrm{C}_{\mathrm{N}}\right)$ & 0.02 & 0.04 & 1107.1 \\
\hline 0.003 & $\mu_{\mathrm{A}}=0.03 \mathrm{C}_{\mathrm{N}} /\left(0.15+\mathrm{C}_{\mathrm{N}}\right)$ & 0.03 & 0.05 & 738.1 \\
\hline 0.004 & $\mu_{\mathrm{A}}=0.04 \mathrm{C}_{\mathrm{N}} /\left(0.15+\mathrm{C}_{\mathrm{N}}\right)$ & 0.04 & 0.07 & 553.6 \\
\hline 0.005 & $\mu_{\mathrm{A}}=0.05 \mathrm{C}_{\mathrm{N}} /\left(0.15+\mathrm{C}_{\mathrm{N}}\right)$ & 0.05 & 0.09 & 442.9 \\
\hline 0.006 & $\mu_{\mathrm{A}}=0.05 \mathrm{C}_{\mathrm{N}} /\left(0.15+\mathrm{C}_{\mathrm{N}}\right)$ & 0.05 & 0.10 & 369.0 \\
\hline 0.007 & $\mu_{\mathrm{A}}=0.06 \mathrm{C}_{\mathrm{N}} /\left(0.15+\mathrm{C}_{\mathrm{N}}\right)$ & 0.06 & 0.11 & 316.3 \\
\hline 0.008 & $\mu_{\mathrm{A}}=0.07 \mathrm{C}_{\mathrm{N}} /\left(0.15+\mathrm{C}_{\mathrm{N}}\right)$ & 0.07 & 0.13 & 276.8 \\
\hline 0.009 & $\mu_{\mathrm{A}}=0.07 \mathrm{C}_{\mathrm{N}} /\left(0.15+\mathrm{C}_{\mathrm{N}}\right)$ & 0.07 & 0.14 & 246.0 \\
\hline 0.01 & $\mu_{\mathrm{A}}=0.08 \mathrm{C}_{\mathrm{N}} /\left(0.15+\mathrm{C}_{\mathrm{N}}\right)$ & 0.08 & 0.15 & 221.4 \\
\hline 0.02 & $\mu_{\mathrm{A}}=0.13 \mathrm{C}_{\mathrm{N}} /\left(0.15+\mathrm{C}_{\mathrm{N}}\right)$ & 0.13 & 0.24 & 110.7 \\
\hline 0.03 & $\mu_{\mathrm{A}}=0.16 \mathrm{C}_{\mathrm{N}} /\left(0.15+\mathrm{C}_{\mathrm{N}}\right)$ & 0.16 & 0.30 & 73.8 \\
\hline 0.04 & $\mu_{\mathrm{A}}=0.18 \mathrm{C}_{\mathrm{N}} /\left(0.15+\mathrm{C}_{\mathrm{N}}\right)$ & 0.18 & 0.34 & 55.4 \\
\hline 0.05 & $\mu_{\mathrm{A}}=0.20 \mathrm{C}_{\mathrm{N}} /\left(0.15+\mathrm{C}_{\mathrm{N}}\right)$ & 0.20 & 0.38 & 44.3 \\
\hline 0.06 & $\mu_{\mathrm{A}}=0.21 \mathrm{C}_{\mathrm{N}} /\left(0.15+\mathrm{C}_{\mathrm{N}}\right)$ & 0.21 & 0.40 & 36.9 \\
\hline 0.07 & $\mu_{\mathrm{A}}=0.22 \mathrm{C}_{\mathrm{N}} /\left(0.15+\mathrm{C}_{\mathrm{N}}\right)$ & 0.22 & 0.42 & 31.6 \\
\hline 0.08 & $\mu_{\mathrm{A}}=0.23 \mathrm{C}_{\mathrm{N}} /\left(0.15+\mathrm{C}_{\mathrm{N}}\right)$ & 0.23 & 0.44 & 27.7 \\
\hline 0.09 & $\mu_{\mathrm{A}}=0.24 \mathrm{C}_{\mathrm{N}} /\left(0.15+\mathrm{C}_{\mathrm{N}}\right)$ & 0.24 & 0.45 & 24.6 \\
\hline 0.1 & $\mu_{\mathrm{A}}=0.24 \mathrm{C}_{\mathrm{N}} /\left(0.15+\mathrm{C}_{\mathrm{N}}\right)$ & 0.24 & 0.46 & 22.1 \\
\hline 0.2 & $\mu_{\mathrm{A}}=0.28 \mathrm{C}_{\mathrm{N}} /\left(0.15+\mathrm{C}_{\mathrm{N}}\right)$ & 0.28 & 0.52 & 11.1 \\
\hline 0.3 & $\mu_{\mathrm{A}}=0.29 \mathrm{C}_{\mathrm{N}} /\left(0.15+\mathrm{C}_{\mathrm{N}}\right)$ & 0.29 & 0.55 & 7.4 \\
\hline 0.4 & $\mu_{\mathrm{A}}=0.30 \mathrm{C}_{\mathrm{N}} /\left(0.15+\mathrm{C}_{\mathrm{N}}\right)$ & 0.30 & 0.56 & 5.5 \\
\hline 0.5 & $\mu_{\mathrm{A}}=0.30 \mathrm{C}_{\mathrm{N}} /\left(0.15+\mathrm{C}_{\mathrm{N}}\right)$ & 0.30 & 0.57 & 4.4 \\
\hline 0.6 & $\mu_{\mathrm{A}}=0.30 \mathrm{C}_{\mathrm{N}} /\left(0.15+\mathrm{C}_{\mathrm{N}}\right)$ & 0.30 & 0.57 & 3.7 \\
\hline 0.7 & $\mu_{\mathrm{A}}=0.30 \mathrm{C}_{\mathrm{N}} /\left(0.15+\mathrm{C}_{\mathrm{N}}\right)$ & 0.30 & 0.58 & 3.2 \\
\hline 0.8 & $\mu_{\mathrm{A}}=0.31 \mathrm{C}_{\mathrm{N}} /\left(0.15+\mathrm{C}_{\mathrm{N}}\right)$ & 0.31 & 0.58 & 2.8 \\
\hline 0.9 & $\mu_{\mathrm{A}}=0.31 \mathrm{C}_{\mathrm{N}} /\left(0.15+\mathrm{C}_{\mathrm{N}}\right)$ & 0.31 & 0.58 & 2.5 \\
\hline 1.0 & $\mu_{\mathrm{A}}=0.31 \mathrm{C}_{\mathrm{N}} /\left(0.15+\mathrm{C}_{\mathrm{N}}\right)$ & 0.31 & 0.58 & 2.2 \\
\hline
\end{tabular}

\section{Discussion}

\section{Effects of $\mathrm{N}$ and $\mathrm{P}$ on the Growth of $M$. densa}

$\mathrm{N}$ concentrations in subtropical and tropical reservoirs varied greatly from $0.1 \sim 4 \mathrm{mg} \mathrm{l}^{-1}[33,34]$. Algae species chose suitable $\mathrm{N}$ concentration for their growth. For $M$. densa, it could live well in a wide range of $\mathrm{N}$ concentrations which was from 0.05 to $40 \mathrm{mg} \mathrm{N}^{-1}$ (Fig. 2a). It meant that $M$. densa could survive in most waters. When the $\mathrm{N}$ concentration could not satisty the growth of other algae, $M$. densa could still survive and continue to growth, which might be one of the reasons why it bloomed in Lianhe Reservoir. In order to demonstrate the superiority of $M$. densa in population competition, more experiments are needed.

There was no significant difference in the time of $M$. densa reaching the exponential growth stage and the stationary phase under different $\mathrm{N}$ concentrations. It indicated that $\mathrm{N}$ concentration did not affect the growth cycle of $M$. densa cells. The specific growth rate and the maximum cell density of $M$. densa increased 
Table 3. Summary statistics of available average data from Lianhe Reservoir in June, July and August 2015 2017 and Liuxihe Reservoir in June, July, August and September 2014 2018.

\begin{tabular}{|c|c|c|c|c|c|c|}
\hline & \multicolumn{3}{|c|}{ Lianhe Reservoir } & \multicolumn{3}{c|}{ Liuxihe Reservoir } \\
\hline & Minimum & Maximum & Mean & Minimum & Maximum & Mean \\
\hline $\mathrm{WT}\left({ }^{\circ} \mathrm{C}\right)$ & 31.1 & 34.5 & 33.2 & 31.7 & 34.3 & 32.9 \\
\hline $\mathrm{pH}$ & 7.8 & 8.7 & 8.1 & 7.6 & 8.9 & 8.2 \\
\hline $\mathrm{DO}$ & 8.0 & 9.7 & 8.7 & 7.8 & 9.5 & 8.2 \\
\hline $\mathrm{NO}_{3}^{-}-\mathrm{N}\left(\mathrm{mg} \mathrm{l}^{-1}\right)$ & 0.10 & 1.20 & 0.59 & 0.13 & 1.52 & 0.71 \\
\hline $\mathrm{PO}_{4}^{3-}-\mathrm{P}\left(\mathrm{mg} \mathrm{l}^{-1}\right)$ & 0.043 & 0.057 & 0.049 & 0.011 & 0.015 & 0.013 \\
\hline
\end{tabular}

with the increasing of $\mathrm{N}$ concentration. However, when $\mathrm{N}$ concentration was higher than $8 \mathrm{mg} \mathrm{l}^{-1}$, the cell growth curves tended to be consistent. These results suggested that the concentration of approximately $8 \mathrm{mg} \mathrm{l}^{-1}$ was the maximum threshold of $M$. densa for $\mathrm{N}$ demand. This concentration was significantly higher than the $\mathrm{N}$ concentration in most lakes and reservoirs $[35,36]$, which suggested that $M$. densa could grow rapidly in most waters and $\mathrm{N}$ concentrations in natural waters would not restrict the growth of $M$. densa.

The Redfield ratio has long been regarded as the optimum allocation of nitrogen and phosphorus for algal metabolism [37]. However, the ratio of N:P was more than 16:1 in the lakes and reservoirs where Microcystis blooms occurred, such as the Lianhe Reservoir, Liuxihe Reservoir, Chopim Reservoir, and Salto Grande Reservoir [38, 39]. The low concentration of $\mathrm{P}$ in ambient environment affects the intracellular $\mathrm{P}$ storage. Therefore, Microcystis possesses a variety of mechanisms to enhance $\mathrm{P}$ uptake and storage in response to $\mathrm{P}$ deficiency or starvation. In this study, $\mathrm{P}$ concentration at a very low level $\left(0.001 \sim 0.01 \mathrm{mg} \mathrm{l}^{-1}\right)$ could also promote algal cells to enter the exponential growth stage (Fig. 2b). It indicated that the cell density of $M$. densa seemed to be unaffected by low $\mathrm{P}$ concentrations. The reason for these might be that the $\mathrm{K}$ of $M$. densa for $\mathrm{P}$ was $0.03 \pm 0.00 \mathrm{mg} \mathrm{l}^{-1}$, which was significantly lower than that for $\mathrm{N}$ $\left(0.15 \pm 0.02 \mathrm{mg} \mathrm{l}^{-1}\right)$ (Table 1) $(P<0.05)$. This indicated that the $M$. densa cells had a high affinity with $\mathrm{P}$ and could still take up $\mathrm{P}$ while the concentration was very low, even near the detection limit. We suggest that $M$. densa cells, which tolerate low P for a long time, have adapted to their surroundings. $M$. densa can grow faster than other species who can not adapt to low P environments, which may be another reason for the bloom. Surely, this viewpoint also needed more experiments to confirm.

Even the $\mathrm{P}$ concentration was at low level (0.001 0.01 mg $\left.\mathrm{l}^{-1}\right), \quad M$. densa still continued to proliferate (Fig. 2b). When the P concentration exceeded $0.7 \mathrm{mg} \mathrm{l}^{-1}$, the values of $\mu_{\text {max }-\mathrm{A}}\left(0.31 \mathrm{~d}^{-1}\right)$ and $\mu_{\mathrm{p}}\left(0.58 \mathrm{~d}^{-1}\right)$ were invariant, which suggested that the $\mathrm{P}$ pool in the $M$. densa cells was saturated and no longer required external P (Table 2). This showed that $M$. densa cells had a high $\mathrm{P}$ storage capacity and maintained a high $\mathrm{P}$ uptake rate. Species such as some of Microcystis are considered to be better suited for a low P environment as a survival strategy for environmental adaptation. They have the high ability to scavenge for available $\mathrm{P}$ to allow them to out-compete other species and be the dominant species in the phytoplankton community. Other studies also mentioned that Microcystis could
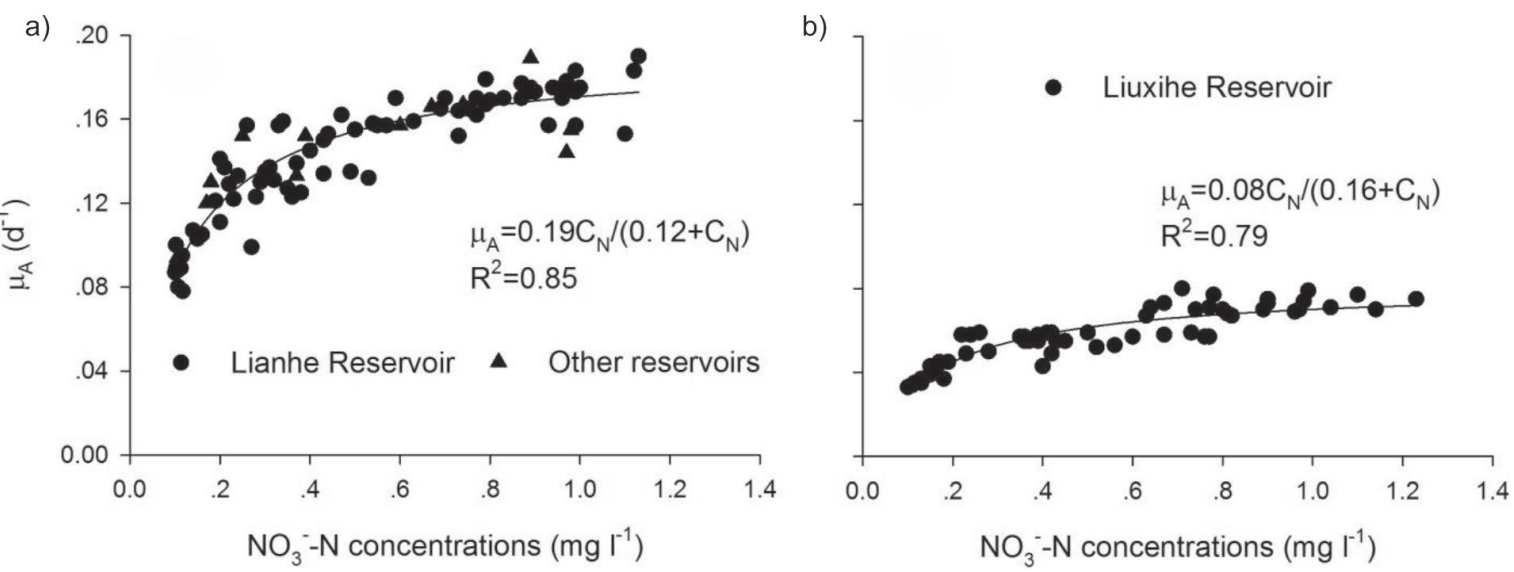

Fig. 5. The relationship of the specific growth rates of $M$. densa $\left(\mu_{\mathrm{A}}\right)$ in response to the $\mathrm{NO}_{3}^{-}-\mathrm{N}^{-}$concentrations $\left(\mathrm{C}_{\mathrm{N}}\right)$ when a) the $\mathrm{PO}{ }_{4}^{3-}-\mathrm{P}$ concentration was $0.05 \mathrm{mg} \mathrm{l}^{-1}$ based on the actual measures of Lianhe Reservoir (solid circles) and other studies (solid triangles) and when b) the $\mathrm{PO}_{4}^{3-}-\mathrm{P}$ concentration was $0.01 \mathrm{mg} \mathrm{l}^{-1}$ based on the actual measures of Liuxihe Reservoir (solid circles). 
consistently accumulate the newly P [40] and had a high efficiency for $\mathrm{P}$ utilization to cause an algal bloom [18].

\section{Comparing with Other Common Microcystis Species}

Microcystis aeruginosa are a common Microcystis species in many eutrophic lakes and reservoirs [41]. We took $M$. aeruginosa as a typical example and compared the growth characteristics between $M$. densa and $M$. aeruginosa. Many studies showed that M. aeruginosa had the competitive advantage only under high $\mathrm{N}$ concentration and low $\mathrm{N}$ concentration would hinder the growth of $M$. aeruginosa [41, 42]. However, M. densa cells could reached the exponential growth stage when $\mathrm{N}$ concentration was from 0.05 to $40 \mathrm{mg} \mathrm{l}^{-1}$ (Fig. 2). It is generally believed that if $\mathrm{N}$ concentration was higher than $0.2 \mathrm{mg} \mathrm{l}^{-1}$ and $\mathrm{P}$ concentration was higher than $0.02 \mathrm{mg} \mathrm{l}^{-1}$, the waters was in an eutrophication state. Therefore, $M$. densa could multiply rapidly in both oligotrophic and eutrophic waters, which indicated that $M$. densa had a wider survival scope comparing with $M$. aeruginosa. N concentration was not the primary environmental factor that restricted the growth of $M$. densa, but it was a constrain for M. aeruginosa.

In this study, the specific growth rates of $M$. densa were from $0.01 \sim 0.31 \mathrm{~d}^{-1}$ (Table 2). But the average growth rate of $M$. aeruginosa was approximately $0.37 \mathrm{~d}^{-1}$ [43], and sometimes this value even reached $0.64 \mathrm{~d}^{-1}$ [44]. Obviously, the specific growth rate of $M$. densa was lower than that of $M$. aeruginosa, which meant that it took longer for $M$. densa cells to transition to the stationary phase. Meanwhile, our study showed that the lower ratios of $\mathrm{N}: \mathrm{P}$, the higher the specific growth rate of $M$. densa (Table 2). But some studies showed that $\mathrm{N}: \mathrm{P}$ ratio did not influence the growth rate of $M$. aeruginosa [45], which was different from the situation of $M$. densa. Therefore, the growth of $M$. densa seemed to be more influenced by the ambient nutrient concentration and lower $\mathrm{N}: \mathrm{P}$ ratio would favor the growth of M.densa.

\section{Environmental Implications}

M. densa is a novel bloom species observed in recent years, taking up and assimilating nitrogen and phosphorus from ambient environment for rapid growth. It was been indicated that the frequent occurrence of Microcystis blooms was closely related to increasing $\mathrm{N}$ or $\mathrm{P}$ inputs in fresh waters $[16,46]$. Many studies focused on a single nutrient as the substrate and their monotonic relationship with Microcystis. These studies surely helped understanding the uptake and assimilation of Microcystis for N and P [17-19, 47]. However, N and P coexisted in water column and could be simultaneously taken up by $M$. densa cells for growth and metabolism. Our study focused on the growth response of $M$. densa to both $\mathrm{N}$ and $\mathrm{P}$ as substrates and evaluated the growth model combined with $\mathrm{N}$ and $\mathrm{P}$. It is hoped that our results could contribute to understanding the growth of $M$. densa in utilizing both $\mathrm{N}$ and $\mathrm{P}$ and the prediction of the cell densities of $M$. densa based on $\mathrm{N}$ and $\mathrm{P}$ concentrations.

Assuming the $\mathrm{P}$ concentration, a modified model provided a prediction of the cell densities of $M$. densa using the least number of input parameters. A crucial implication of a modified model was that the concentrations of $\mathrm{N}$ and $\mathrm{P}$ both controlled the growth rates of $M$. densa. For a water column with different nutrient levels, such as oligotrophic, mesotrophic, or eutrophic lakes and reservoirs, calculating the specific growth rate might be accomplished using a different $\mu_{\max }$ and $\mathrm{K}$ of $M$. densa. The equation proposed by Monod [27] was a promising method to describe the growth kinetics of $M$. densa and determine the parameters. As long as the $\mathrm{N}$ and $\mathrm{P}$ concentrations in the water column were determined, the specific growth rate and growth status of $M$. densa could be predicted.

The annual variations of $\mathrm{N}$ and $\mathrm{P}$ concentrations in lakes or reservoirs are a dynamic process. The concentrations of $\mathrm{N}$ and $\mathrm{P}$ are usually low in reservoirs when they are first formed. Then, the concentrations increase steadily year by year from oligotrophic to mesotrophic and even eutrophic. The Lianhe Reservoir, built in the 1970s, had no previous algal bloom until 2012. According past data of $\mathrm{N}$ and $\mathrm{P}$ concentrations, we believed that the growth trajectory of $M$. densa in the past several decades could be deduced. Moreover, the water column where $M$. densa are suited to grow in the waters with the same physical and chemical environment characteristics, such as higher water temperature, lower disturbance, and enough dissolved oxygen content. Therefore, this modified model is hoped to apply to all subtropical reservoirs which suffer $M$. densa bloom. Of course, this model needs to be validated in more reservoirs and further refined. We still believed that this model is conducive to the reservoir management office to find growth status of $M$. densa in time and take early measures to prevent the further outbreak of $M$. densa.

\section{Conclusions}

A modified model with Monod kinetics was built to describe the synergetic respond of $M$. densa growth to different concentrations of $\mathrm{N}$ and $\mathrm{P}$. The specific growth rate of $M$. densa can be calculated according to $\mathrm{N}$ and $\mathrm{P}$ concentrations in water column. This model was verified by the actual measures of the two typical subtropical reservoirs and could relatively accurately predict the growth level of $M$. densa. Moreover, $\mathrm{N}$ and $\mathrm{P}$ are equally important for the growth of $M$. densa. Therefore, our study helped for the daily monitoring of reservoir management for $M$. densa growth and understanding the synergetic effect of $\mathrm{N}$ and $\mathrm{P}$ to M. densa growth. 


\section{Acknowledgments}

We thank the editor and reviewers for their insightful comments and suggestions. We also acknowledge Yingjie Cao, Shuyuan Wang, Jingsi Cui for assistance with sampling in this study. This research was supported by National Natural Science Foundation of China (grant number 41877470) and the Natural Science Foundation of Guangdong Province, China (No. 2017A030313229).

\section{Conflict of Interest}

The authors declare no conflict of interest.

\section{References}

1. KRAUSFELDT L.E., STEFFEN M.M., MCKAY R. M., BULLERJAHN G.S., BOYER G.L., WILHELM S.W. Insight into the molecular mechanisms for microcystin biodegradation in Lake Erie and Lake Taihu. Front. Microbiol. 10, 2741, 2019.

2. CHEN X., HUANG Y., CHEN G., LI P., SHEN Y., DAVIS T.W. The secretion of organics by living Microcystis under the dark/anoxic condition and its enhancing effect on nitrate removal. Chemosphere. 196, 280, 2018.

3. RACINE M., SALEEM A., PICK F.R. Metabolome variation between strains of Microcystis aeruginosa by untargeted mass spectrometry. Toxins. 11 (12), 723, 2019.

4. CAI Y., CAO Y., TANG C. Evidence for the primary role of phytoplankton on nitrogen cycle in a subtropical reservoir: reflected by the stable isotope ratios of particulate nitrogen and total dissoloved nitrogen. Front. Microbiol. 10, 2202, 2019.

5. HU H., WEI Y. The freshwater algae of China-systematics, taxonomy and ecology; Science Press: Beijing, China, pp. 61-79, 2006 [In Chinese].

6. O' NEIL J.M., DAVIS T.W., BURFORD M.A., GOBLER C.J. The rise of harmful cyanobacteria blooms : the potential roles of eutrophication and climate change. Harmful Algae. 14, 313, 2012.

7. PAERL H.W., OTTEN T.G. Harmful cyanobacterial blooms: cause, consequence, and controls. Microbial Ecology. 65, 995, 2013.

8. GAO G., XIA J., YU J., ZENG X. Physiological response of a red tide alga (Skeletonema costatum) to nitrate enrichment, with special reference to inorganic carbon acquisition. Mar. Environ. Res. 133, 15, 2018.

9. BURBERG C., ILIC M., PETZOLDT T., VON ELERT E. Nitrate determines growth and protease inhibitor content of the cyanobacterium Microcystis aeruginosa. J. Appl. Phycol. 31 (3), 1697, 2019.

10. AMONO Y., TAKAHASHI K., MACHIDA M. Competition between the cyanobacterium Microcystis aeruginosa and the diatom Cyclotella sp. Under nitrogenlimited condition caused by dilution in eutrophic lake. J. Appl. Phycol. 24, 965, 2012.

11. KIM H., JO B.Y., KIM H.S. Effect of different concentrations and ratios of ammonium, nitrate, and phosphorus on growth of the blue-green alga (cyanobacterium) Microcystis aeruginosa isolated from the Nakdong River, Korea. Algae. 32(4), 275, 2017.
12. COLLOS Y., HARRISON P.J. Acclimation and toxicity of high ammonium concentrations to unicellular algae. Mar. Pollut. Bull. 80, 8, 2014.

13. DING D.B., CHEN S.S., PENG S.P., JIANG C.Y., ZHENG L.L., LI J. Strategies of phosphorus utilization in an astaxanthin-producing green alga Haematococcus pluvialis, a comparison with a bloom-froming cyanobacterium Microcystis wesenbergii. Aquat. Ecol. 53 (4), 679, 2019.

14. KUNZ M.J., WÜEST A., WEHRLI B., LANDERT J., SENN D.B. 2011. Impact of a large tropical reservoir on riverine transport of sediment, carbon, and nutrients to downstream wetlands. Water Resour. Res. 47 (12), W12531, 2011.

15. FIGUEREDO C.C., VON RÜCKERT G., CUPERTINO A., PONTES M.A., FERNANDES L. A., RIBEIRO S.G., MARAN N.R.C. Lack of nitrogen as a causing agent of Cylindrospermopsis raciborskii intermittent blooms in a small tropical reservoir. FEMS Microbiol. Ecol. 87 (3), 557, 2014.

16. ZHEN Y., KONG F., SHI X., YU Y., ZHANG M. UV-B radiation and phosphorus limitation interact to affect the growth, pigment content, and photosynthesis of the toxic cyanobacterium Microcystis aeruginosa. J. Appl. Phycol. 26 (4), 1669, 2014.

17. PRENTICE M.J., O'BRIEN K.R., HAMILTON D.P., BURFORD M. A. High- and low-affinity phosphate uptake and its effect on phytoplankton dominance in a phosphatedepauperate lake. Aquat. Microb. Ecol. 75, 139, 2015.

18. DAVIS C.E., MAHAFFEY C. Elevated alkaline phosphatase activity in a phosphate-replete environment: Influence of sinking particles. Limnol. Oceanogr. 62 (6), 2389, 2017.

19. OU L., QIN X., SHI X., FENG Q., ZHANG S., LU S., QI Y. Alkaline phosphatase activities and regulation in three harmful Prorocentrum species from the coastal waters of the East China Sea. Microb. Ecol. 79, 459, 2020.

20. LI Y., WAITE A.M., GAL G., HIPSEY M.R. An analysis of the relationship between phytoplankton internal stoichiometry and water column N:P ratios in a dynamic lake environment. Ecol. Model. 252 (1), 196, 2013.

21. ZHU W., SUN Q., CHEN F., LI M. Cellular N:P ration of Microcystis as an indicator of nutrient limitationimplications and applications. Environ. Earth Sci. 74, 4023, 2015.

22. LOLADZE I., ELSER J. The origins of the Redfield nitrogen-to-phosphorus ratio are in a homoeostatic protein -to-rRNA ratio. Ecol. Lett. 14, 244, 2011.

23. O'DONNELL D.R., WILBURN P., SILOW E.A., YAMPOLSKY E.Y., LITCHMAN E. Nitrogen and phosphorus colimitation of phytoplankton in Lake Baikal: Insights from a spatial survey and nutrient enrichment experiments. Limnol. Oceanogr. 62(4), 2017.

24. ZHOU Y., ZHANG Y., LIANG T., WANG L. Shifting of phytoplankton assemblages in a regulated Chinese river basin after streamflow and water quality changes. Science of The Total Environment. 654, 948, 2019.

25. STANIER R.Y., KUNISAWA R., MANDEL M., COHENBAZIRE G. Purification and properties of unicellular blue-green algae (order Chroococcales). Bacteriological Reviews 35, 171, 1971.

26. GUILLARD R.R.I. Methods for microflagellates and nanoplankton. In Handbook of phycological methods: culture methods and growth measurements; Stein J.R. Ed., Cambridge University Press: Cambridge, UK, pp. 69, 1973. 
27. MONOD J. The growth of bacterial cultures. Ann. Rev. Microbiol. 3, 139, 1949.

28. American Public Health Association (APHA), American Water Works Association (AWWA) and Water Environment Federation (WEF). Standard Methods for the Examination of Water and Wastewater, 19th ed.; APHA: Washington DC, USA, 1995.

29. MOWE M.A.D., ABBAS F., POROJAN C., MITROVIC S.M., LIM R.P., FUREY A., YEO D.C.J. Roles of nitrogen and phosphorus in growth responses and toxin production (using LC-MS/MS) of tropical Microcystis ichthyoblabe and M. flos-aquae. J. Appl. Phycol. 28, 1543, 2016.

30. PUDDICK J., PRINSEP M.R., WOOD S.A., CARY S.C., HAMILTON D.P. Modulation of microcystin congener abundance following nitrogen depletion of a Microcystis batch culture. Aquatic Ecology. 50, 235, 2016.

31. CHIA M.A., CORDEIRO-ARAÚJO M.K., LORENZI A.S., BITTENCOURT-OLIVEIRA M.C. Cylindrospermopsin induced changes in growth, toxin production and antioxidant response of Acutodesmus acuminatus and Microcystis aeruginosa under differing light and nitrogen conditions. Ecotox. Environ. Safe. 142, 189, 2017.

32. GHAFFAR S., STEVENSON R.J., KHAN Z. Effect of phosphorus stress on Microcystis aeruginosa growth and phosphorus uptake. PloS One. 12, e0174349, 2017.

33. TONG Y., LI J., QI M., ZHANG X., WANG M., LIU X., ZHANG W., WANG X., LU Y., LIN Y. Impacts of water residence time on nitrogen budget of lakes and reservoirs. Sci. Total Environ. 646 (1), 75, 2019.

34. HAMILTON T.L., CORMAN J.R., HAVIG J.R. Carbon and nitrogen recycling during cyanoHABs in dreissedidinvaded and non-invaded US midwestern lakes and reservoirs. Hydrobiologia. 847, 939, 2020.

35. BOËCHAT I.G., PAIVA-MAGELA A.B.D., REIS, H.R., GÜCKER B. Dissolved organic $\mathrm{N}$ in shallow tropical lakes and reservoirs: Contribution to total dissolved $\mathrm{N}$ and relationships with eutrophication. Int. Rev. Hydrobiol. 104, 106, 2019.

36. CAI J., BAI C., TANG X., DAI J., JIANG X., H Y., SHAO K., GAO G. Spatiotemporal variations in seston $\mathrm{C} ; \mathrm{N} ; \mathrm{P}$ stoichiometry in a large eutrophic floodplain lake (Lake Taihu): Do the sources of seston explain stoichiometric flexibility? Water. 12 (1), 36, 2020.

37. LOLADZE I., ELSER J.J. Origins of the Redfield nitrogento-phosphorus ratio ratio are in a homoeostatic protein-torRNA ratio. Ecology Letters. 14 (3), 244, 2011.
38. O'FARRELL I., BORDET F., CHAPARRO G. Bloom forming cyanobacterial complexes co-occurring in a subtropical large reservoir: validation of dominant ecostrategies. Hydrobiologia. 698, 175, 2012.

39. WOJCIECHOWSKI J., HEINO J., BINI L.M., PADIAL A.A. Temporal variation in phytoplankton beta diversity patterns and metacommunity structures across subtropical reservoirs. Freshwater Biology. 62, 751, 2017.

40. ZHENG Y., MI W., BI Y., HU Z. The response of phosphorus uptake strategies of Microcystis aeruginosa to hydrodynamics fluctuations. Environ. Sci. Pollut. Res. 24 (10), 9251, 2017.

41. YANG Z., GENG L., WANG W., ZHANG J. Combined effects of temperature, light intensity, and nitrogen concentration on the growth and polysaccharide content of Microcystis aeruginosa in batch culture. Biochem. Syst. Ecol. 41, 130, 2012

42. WANG Z., ZHANG Y., HUANG S., PENG C., HAO Z. Nitrogen limitation significantly reduces the competitive advantage of toxic Microcystis at high light conditions. Chemosphere. 237, 124508, 2019.

43. AMANO Y., TAKAHASHI K., MACHIDA M. Competition between the cyanobacterium Microcystis aeruginosa and the diatom Cyclotella $\mathrm{sp}$. Under nitrogenlimited condition caused by dilution in eutrophic lake. J. Appl. Phycol. 24, 965, 2012.

44. ZHEN S., ZHU W. Determination of the in situ growth rate of Microcystis based on carbon and nitrogen stable isotope fractionation. Water Science \& Technology: Water Supply. 18 (3), 984, 2018.

45. MARINHO M.M., DE OLIVEIRA E AZEVEDO S.M.F. Influence of N/P ratio on competitive abilities for nitrogen and phosphorus by Microcystis aeruginosa and Aulacoseira distans. Aquat. Ecol. 41, 525, 2007.

46. XU H., PAERL H.W., QIN B., ZHU G., HALL N.S., WU Y. Determining critical nutrient thresholds needed to control harmful cyanobacterial blooms in eutrophic Lake Taihu, China. Environmental Science and Technology. 49 (2), 1051, 2015.

47. GLIBERT P.M., WILKERSON F.P., DUGDALE R.C., RAVEN J.A., DUPONT C.L., LEAVITT P.R., PARKER A.E., BURKHOLDER J.M., KANA T.M. Pluses and minuses of ammonium and nitrate uptake and assimilation by phytoplankton and implications for productivity and community composition, with emphasis on nitrogenenriched conditions. Limnol. Oceanogr. 61 (1), 165, 2016. 
